\title{
Evaluation of Best Dose of Micronutrients (Zinc, Iron and Boron) to Combat Malnutrition in Brinjal (Solanum melongena L.)
}

\section{Zafar Abbas ${ }^{1 *}$, Shahzada Munawar Mehdi², Muhammad Nasir ${ }^{3}$, Muhammad Ashraf ${ }^{4}$, Salma Kausar Nadeem Iqbal $^{6}$, Muhammad Zahid Khan Nazar ${ }^{7}$, Iftikhar Ahmad ${ }^{3}$, Ghulam Murtaza ${ }^{1}$ and Ijaz Ahmad ${ }^{8}$}

${ }^{1}$ Soil Fertility Research Wing, Bahawalpur-63100, Pakistan; ${ }^{2}$ Soil Fertility Research Institute Punjab, Lahore, Pakistan; ${ }^{3}$ Soil Fertility Research Wing, Multan, Pakistan; ${ }^{4}$ Soil and Water Testing Laboratory, Bahawalpur, Pakistan; ${ }^{5}$ Soil and Water Testing Laboratory, Lodhran, Pakistan; ${ }^{6}$ Soil Fertility Research Wing, Faisalabad, Pakistan; ${ }^{7}$ Soil Fertility Research Wing, Bahawalnagar, Pakistan; ${ }^{8}$ Ecotoxicology Research Institute, National Agricultural Research Centre, Islamabad, Pakistan.

Abstract | The study was carried out in the farmer's fields of Bahawalpur during Kharif-2018 and Kharif-2019 to examine the impact of different doses of micronutrients ( $\mathrm{Zn}, \mathrm{Fe}$ and Boron) on the yield and quality of brinjal. The experiment was laid out in Randomized Complete Block Design (RCBD) with three replications. Five different levels of micronutrients were applied. The treatment $\mathrm{T}_{5}$ i.e. $(100-60-50)+$ Borax $(0.2)+\mathrm{ZnSO} 4$ $(0.5 \%)+\mathrm{FeSO}_{4}(0.5 \%)$ exhibited maximum plant height, fruit weight, total yield, number of fuits plant ${ }^{-1}$ and survival percentage except number of leaves plant $^{-1}$ which were maximum in $\mathrm{T}_{4}$ i.e. (100-60-50)+ $\mathrm{ZnSO} 4$ $0.5 \%$. Concludingly, growth parameters of all the theree cultivars of egg plant showed maximum performance i.e plant height $(88.57,139.77$ and $135.11 \mathrm{~cm})$, fruit weight $(213,284$ and $261 \mathrm{~g})$, yield $(10.11,11.98$ and $\left.12.39 \mathrm{t} \mathrm{ha}^{-1}\right)$, survival percentage $(95.71,99.63$ and $90.23 \%)$ and number of fruits per plant $(9.81,8.67$ and 8.11) due to $\mathrm{T}_{5}$ in black boy, twinkle star and shamli varieties, respectively. Hence, Borax $(0.2)+\mathrm{ZnSO}_{4}$ $(0.5 \%)+\mathrm{FeSO}_{4}(0.5 \%) \mathrm{kg} \mathrm{ha}^{-1}$ is recommended as best dose of micronutrient for brinjal.

Received | November 24, 2020; Accepted | December 16, 2020; Published | March 03, 2021

*Correspondence | Zafar Abbas, Soil Fertility Research Wing, Bahawalpur-63100, Pakistan; Email: zafarmahmood390@gmail.com

Citation | Abbas, Z., S.M. Mehdi, M. Nasir, M. Ashraf, S. Kausar, N. Iqbal, M.Z.K. Nazar, I. Ahmad, G. Murtaza and I. Ahmad. 2021. Evaluation of best dose of micronutrients (Zinc, Iron and Boron) to combat malnutrition in brinjal (Solanum melongena L.). Pakistan Journal of Agricultural Research, 34(1): 164-168.

DOI | http://dx.doi.org/10.17582/journal.pjar/2021/34.1.164.168

Keywords | Micronutrients, Evaluation, Malnutrition, Combat, Brinjal

\section{Introduction}

$\mathrm{B}$ rinjal (Solanum melongena L.) also called as Egg plant is one of the most important vegetable of Pakistan. It is also grown in Japan, Turkey, Egypt, Indonesia and Italy. It belongs to family solanaceae. It contains phosphorus, different vitamins particularly $\mathrm{B}$-complex. Bringal is considered as rich source of fiber and help in regulating the level of sugar in blood. The phenolics present in eggplant inhibit the enzymes involved with type 2 diabetes (Kumar and Sodh, 2015). Proper nutrition of plants is vital for increased yield and better quality of bringal. There is a dare need to adopt balanced use of both macro and micronutrients as micronutrient play vital role in different metabolic processes in plants. If nutrients are not applied to plants adequately ultimately the plants will go under stress with concomitant decrease in yield (Fageria, 2009). In our country we are getting very low yield of vegetables because of imbalanced use of fertilizers. As we are using only macronutrients (NPK) to vegetables but the use of micronutrients ( $\mathrm{Zn}, \mathrm{Fe}$ and B) is meager. Sankaran et al. (2005) also reported decline in yield of different vegetable due to imbalance use of fertilizers. This study was conducted with the objectives to evaluate the best dose of 
fertilizers to combat brinjal malnutrition.

\section{Materials and Methods}

The experiment "Evaluation of best dose of micronutrients (zinc iron and boron) for brinjal to combat malnutrition" was carried out in the farmer's fields of Bahawalpur during Kharif-2018 and Kharif-2019.

\section{Soil sampling and analysis}

The soil samples were taken from the experimental site prior to sowing of eggplant. The samples were analyzed to evaluate the status of the fertility of experimental sites. Soil texture was clay loam, $\mathrm{pH}$ was 7.9 the electrical conductivity (EC) was $0.21 \mathrm{dSm}^{-1}$, soil available $\mathrm{K}$ found to be $180 \mathrm{mg} \mathrm{kg}^{-1}$ and Available

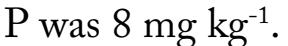

\section{Treatments}

Control, Borax (0.2), $\mathrm{FeSO}_{4}(0.5 \%), \mathrm{ZnSO}_{4}(0.5 \%)$ and Borax (0.2) $+\mathrm{ZnSO}_{4}(0.5 \%)+\mathrm{FeSO}_{4}(0.5 \%)$.

The Survival \%age was computed by using the following formula.

$$
\text { Survival \%age }=\frac{\text { Plant survived }}{\text { Total No. of plants transplanted }} \times 100
$$

The calculation of total yield $\left(\mathrm{t} \mathrm{ha} \mathrm{a}^{-1}\right)$ was done by below given formula:

$$
\text { Total yield }(\mathrm{t} \text { ha }-1)=\frac{\text { Yield per plot }(\text { tones })}{\text { Area of plot }\left(\mathrm{m}^{2}\right)} \times 10^{4} \mathrm{~m}^{2}
$$

\section{Results and Discussion}

\section{Plant height $(\mathrm{cm})$}

The yield data about the plant height of different cultivars of eggplant in response to different doses of micronutrients is given in Table 1. The statistical results revealed significant impact on the plant height of eggplant. The heighest height $(88.75 \mathrm{~cm})$ documented was in $\mathrm{T}_{5}\left\{\right.$ Borax $(0.2)+\mathrm{ZnSO}_{4}(0.5 \%)+\mathrm{FeSO}_{4}$ $(0.5 \%)\}$ lowest plant height was in control $(65.31 \mathrm{~cm})$ in Black boy cultivar. Correspondingly in Twinkle Star cultivar the minimum plant height $(133.26 \mathrm{~cm})$ was in control and maximum plant height (139.77 $\mathrm{cm}$ ) was in $\mathrm{T}_{5}$. Similar trend was observed in Shamli cultivar, where the plant height was maximum was $135.11 \mathrm{~cm}$ in $\mathrm{T}_{5}$.
It is evident that application of micronutrients resulted an increase in the in bringal plant height contrary to control treatment where decreased plant height was noticed. This enhancement in bringal plant height due to micronutrients is attributed towards increase in photosynthesis, formation of chlorophyll and metabolism of nitrogen which inturn increased the plant height. Thesse results are in agreement with the finding of (Kadari et al., 2015; Suganiya and Kumuthini, 2015; Pandav et al., 2016). Increased plant height might be due micronutrients application which acclerated the photosynthesis and formation of chlorophyll and increased auxin contents with concomitant increase in plant height (Gogoi et al., 2014).

Table 1: Impact of micronutrients on Plant height $(\mathrm{cm})$.

\section{Treatments (Kg/ha)}

(100-60-50)

(100-60-50)+Borax 0.2\%

$(100-60-50)+\mathrm{FeSO}_{4} 0.5 \%$

$(100-60-50)+\mathrm{ZnSO}_{4} 0.5 \%$

(100-60-50)+ Borax (0.2)

$+\mathrm{ZnSO}_{4}(0.5 \%)+\mathrm{FeSO}_{4}$

$(0.5 \%)$

Table 2: Impact of micronutrients on fruit weight (g).

\section{Treatments $(\mathrm{Kg} / \mathrm{ha})$}

$(100-60-50)$

(100-60-50)+Borax $0.2 \%$

$(100-60-50)+\mathrm{FeSO}_{4} 0.5 \%$

$(100-60-50)+\mathrm{ZnSO} \quad 0.5 \%$

(100-60-50)+ Borax (0.2)

$+\mathrm{ZnSO}_{4}(0.5 \%)+\mathrm{FeSO}_{4}$

$(0.5 \%)$

\section{Varieties}

Black boy Twinkle star Shamli

65.31

133.26

119.15

125.51

131.22

139.77
93.81

113.54

127.33

131.77

135.11

\section{Varieties}

Black boy Twinkle star Shamli

$163 \quad 185 \quad 155$

$169 \quad 205 \quad 143$

191233

188

267

211

261

\section{Fruit weight (g)}

The data regarding the weight of fruit of different varieties of eggplant is presented in Table 2. The statistical results exposed significant impact on fruit weight of eggplant. The heighest fruit weight $213 \mathrm{~g}$ was experienced in $\mathrm{T}_{5}$ \{ Borax $(0.2)+\mathrm{ZnSO}_{4}(0.5$ $\left.\%)+\mathrm{FeSO}_{4}(0.5 \%)\right\}$ in contrast to control where it was $163 \mathrm{~g}$ in Black boy cultivar. Similarly in case of cultivar Twinkle Star the minimum fruit weght $(185 \mathrm{~g})$ was in control and maximum fruit weight (284 g) was in $T_{5}$ (Table 2). Similar trend was observed in Shamli cultivar, whre it was highest $(261 \mathrm{~g})$ in $\mathrm{T}_{5}$ Fruit 
weight results considerably influenced by different doses of micronutrients. These findings are parallel to those reported by Dubey et al. (2013) who reported increase in fruit weight to micronutrients application.

\section{Total yield ( $\left.t h a^{-1}\right)$}

The data regarding the total yield of different cultivars of eggplant in response to different doses of micronutrients is given in Table 3. The statistical results exposed significant impact on total yield of eggplant. The heighest total yield $\left(10.11 \mathrm{tha}^{-1}\right)$ was noticed in $\mathrm{T}_{5}\left\{\right.$ Borax $\left.(0.2)+\mathrm{ZnSO}_{4}(0.5 \%)+\mathrm{FeSO}_{4}(0.5 \%)\right\}$ lowest yield was in control $\left(4.31 \mathrm{t} \mathrm{ha}^{-1}\right)$ in Black boy cultivar. Correspondingly in Twinkle Star cultivar the minimum total yield $\left(3.78 \mathrm{tha}^{-1}\right)$ was found in control and the highest total yield $\left(11.98 \mathrm{t} \mathrm{ha}^{-1}\right)$ observed was in $\mathrm{T}_{5}$. Likewise tendency was noticed in Shamli cultivar, where the yield was highest $\left(12.39 \mathrm{t} \mathrm{ha}^{-1}\right)$ in $\mathrm{T}_{5}$. Our results are in accordance with the finding of (Khedr et al., 2004) they experienced increase in bringal yield due to micronutrients application.

Table 3: Impact of micronutrients on yield $\left(t h a^{-1}\right)$.

\begin{tabular}{|c|c|c|c|}
\hline \multirow[t]{2}{*}{ Treatments (Kg/ha) } & \multicolumn{3}{|c|}{ Varieties } \\
\hline & Black boy & Twinkle star & Shamli \\
\hline$(100-60-50)$ & 4.21 & 3.78 & 4.13 \\
\hline$(100-60-50)+$ Borax $0.2 \%$ & 6.17 & 5.25 & 5.27 \\
\hline$(100-60-50)+\mathrm{FeSO}_{4} 0.5 \%$ & 8.29 & 9.70 & 8.46 \\
\hline$(100-60-50)+\mathrm{ZnSO}_{4} 0.5 \%$ & 9.13 & 11.81 & 10.21 \\
\hline $\begin{array}{l}(100-60-50)+\operatorname{Borax}(0.2) \\
+\mathrm{ZnSO}_{4}(0.5 \%)+\mathrm{FeSO}_{4} \\
(0.5 \%)\end{array}$ & 10.11 & 11.98 & 12.39 \\
\hline
\end{tabular}

Survival percentage

The reorded data about the Survival \%age of different cultivars of eggplant in response to different doses of micronutrients is given in Table 4. The statistical results exposed significant impact on Survival Percentage of eggplant. Contrary to other parameters under study, the heighest Survival Percentage (95.22\%) was recorded where $\mathrm{T}_{4}\left\{\mathrm{ZnSO}_{4}(0.5 \%)\right\}$ was applied and the lowest Survival Percentage (88.16\%) was in $\mathrm{T}_{3}\left(\mathrm{FeSO}_{4} 0.5 \%\right)$ in Black boy cultivar. In Twinkle Star cultivar the minimum Survival Percentage (85.76\%) was in $\mathrm{T}_{3}$ and maximum $(94.19 \%)$ was in $\mathrm{T}_{2}$ where Borax @0.2\% was used.Opposite tendency was noticed in Shamli cultivar, where the Survival Percentage was highest (94.27\%) in control treatment.

Number of leaves/plant

The data related to the number of leaves plant $^{-1}$ of different cultivars of eggplant in response to different doses of micronutrients is given in Table 5. The results revealed significant effect of micronutrients on the number of leaves plant ${ }^{-1}$ of bringal. In Black Boy cultivar, the maximum number of leaves plant ${ }^{-1}$ were found in $\mathrm{T}_{3}\left(\mathrm{FeSO}_{4} 0.5 \%\right)$ and $\mathrm{T}_{5}$ \{Borax $(0.2 \%)$ $\left.+\mathrm{ZnSO}_{4}(0.5 \%)+\mathrm{FeSO}_{4}(0.5 \%)\right\}$ which were 305 and 283 , respectively. Whereas the minimum number of leaves plant ${ }^{-1}$ (106) were found in $T_{1}$ (control treatment). The Twinkle Star cultivar exhibited the maximum number of leaves plant ${ }^{-1}$ in $T_{3}$ (357) and $\mathrm{T}_{1}$ (352) which were not ststistically significant with each other. Conversely in $\mathrm{T}_{4}$ maximum number of leaves plant ${ }^{-1}(405)$ were observed than control where the number of leaves plant ${ }^{-1}$ were 252 in bringal cultivar Shamli. The foliar application of different micronutrients resulted increase in the the nitrogen content of the leaves. Increase in number of leaves might be attributed toward promotive impacts of micronutrients on the vegetative growth which in turn resulted enhanced photosynthesis (Tawab et al., 2015). Gogoi et al. (2014) also reported parallel results.

Table 4: Impact of micronutrients on survival \%age.

\begin{tabular}{|c|c|c|c|}
\hline \multirow[t]{2}{*}{ Treatments (Kg/ha) } & \multicolumn{3}{|c|}{ Varieties } \\
\hline & Black boy & Twinkle star & Shamli \\
\hline$(100-60-50)$ & 91.21 & 90.14 & 89.11 \\
\hline$(100-60-50)+$ Borax $0.2 \%$ & 93.38 & 91.28 & 88.41 \\
\hline$(100-60-50)+\mathrm{FeSO}_{4} 0.5 \%$ & 96.41 & 92.33 & 90.55 \\
\hline$(100-60-50)+\mathrm{ZnSO}_{4} 0.5 \%$ & 95.55 & 88.72 & 91.71 \\
\hline $\begin{array}{l}(100-60-50)+\operatorname{Borax}(0.2) \\
+\mathrm{ZnSO}_{4}(0.5 \%)+\mathrm{FeSO}_{4} \\
(0.5 \%)\end{array}$ & 95.71 & 99.63 & 90.23 \\
\hline
\end{tabular}

Table 5: Impact of micronutrients on number of leaves/ plant.

\begin{tabular}{llll} 
Treatments $(\mathbf{K g} / \mathbf{h a})$ & \multicolumn{3}{c}{ Varieties } \\
& Black boy & Twinkle star & Shamli \\
$(100-60-50)$ & 101 & 254 & 223 \\
$(100-60-50)+$ Borax $^{0.2 \%}$ & 239 & 289 & 313 \\
$(100-60-50)+\mathrm{FeSO}_{4} 0.5 \%$ & 277 & 301 & 377 \\
$(100-60-50)+\mathrm{ZnSO}_{4} 0.5 \%$ & 282 & 303 & 388 \\
$(100-60-50)+$ Borax $(0.2)$ & 277 & 292 & 403 \\
$+\mathrm{ZnSO}_{4}(0.5 \%)+\mathrm{FeSO}_{4}$ & & & \\
$(0.5 \%)$ & & &
\end{tabular}

\section{Number of fruits plant ${ }^{-1}$}

The number of fruits plant ${ }^{-1}$ data of various eggplant cultivars in response to different doses 
of micronutrients is given in Table 6 . The results exhibited significant effect of micronutrients on number of fruits plant ${ }^{-1}$ of bringal. But in Black Boy cultivar, the maximum number of fruits plant ${ }^{-1}$ were found in $\mathrm{T}_{3}\left(\mathrm{FeSO}_{4} 0.5 \%\right)$ and $\mathrm{T}_{5}$ \{Borax $(0.2 \%)+$ $\left.\mathrm{ZnSO}_{4}(0.5 \%)+\mathrm{FeSO}_{4}(0.5 \%)\right\}$ which were 9.41 and 9.81, respectively. minimum number of fruits plant ${ }^{-1}$ were noticed in $\mathrm{T}_{1}$ (control). The twinkle star cultivar exhibited maximum number of fruits plant ${ }^{-1}$ in $T_{4}$ (8.25) and $\mathrm{T}_{5}$ (8.29). On the other hand in $\mathrm{T}_{3}(7.69)$, $\mathrm{T}_{4}$ (7.88) and $\mathrm{T}_{5}$ (6.860) statistically no significant difference was experienced in case of number of fruits perplant of bringal cultivar Shamli. Mohsin (2013) observed same increase in tomato yield due to iron and zinc application.

Table 6: Impact of micronutrients on number of fruits/ plant.

\begin{tabular}{|c|c|c|c|}
\hline \multirow[t]{2}{*}{ Treatments (Kg/ha) } & \multicolumn{3}{|c|}{ Varieties } \\
\hline & Black boy & Twinkle star & Shamli \\
\hline$(100-60-50)$ & 7.33 & 5.22 & 6.62 \\
\hline$(100-60-50)+$ Borax $0.2 \%$ & 8.11 & 6.13 & 6.98 \\
\hline$(100-60-50)+\mathrm{FeSO}_{4} 0.5 \%$ & 9.41 & 6.97 & 7.69 \\
\hline$(100-60-50)+\mathrm{ZnSO}_{4} 0.5 \%$ & 8.73 & 8.25 & 7.88 \\
\hline $\begin{array}{l}(100-60-50)+\operatorname{Borax}(0.2) \\
+\mathrm{ZnSO}_{4}(0.5 \%)+\mathrm{FeSO}_{4} \\
(0.5 \%)\end{array}$ & 9.81 & 8.67 & 8.11 \\
\hline
\end{tabular}

\section{Conclusions and Recommendations}

Outcmoes of the this study revealed that the growth parameters of all the theree cultivars of egg plant showed maximum performance i.e plant height (88.57, 139.77 and $135.11 \mathrm{~cm})$, fruit weigh (213, 284 and $261 \mathrm{~g}$ ), yield (10.11, 11.98 and $12.39 \mathrm{t} \mathrm{ha}$ $\left.{ }^{1}\right)$, survival percentage $(95.71,99.63$ and $90.23 \%)$ and number of fruits per plant $(9.81,8.67$ and 8.11$)$ due to $\mathrm{T}_{5}$ in Black boy, twinkle star and shamli varieties, respectively. Hence, micronutrients application @ Borax (0.2\%) $+\mathrm{ZnSO}_{4}(0.5 \%)+\mathrm{FeSO}_{4}(0.5 \%)$ is recommended as best dose of micronutrient for egg plant to combat bringal malnutrion alongwith recommended dose of macronutrients as well.

\section{Novelty Statement}

A vast gap between the actual yeld and yield potential of bringal due to insufficient supply of micronutreints is the major cause of bringal malnutrition. Hence, it is inevitable to apply micronutrients ( $\mathrm{Zn}, \mathrm{Fe}$ and Boron) alongwith micronutrients. Application of Borax $(0.2 \%)+\mathrm{ZnSO}_{4}(0.5 \%)+\mathrm{FeSO}_{4}(0.5 \%)$ is hereby proposed to combat bringal malnutrition and to plug in gap between actual yield and potential yield.

\section{Author's Contribution}

The plan of research was proposed by Muhammad Nasir and Nadeem Iqbal, Zafar Abbas, Ghulam Murtaza, Muhammad Zahid Khan Nazar, executed the research, Muhammad Ashraf, contributed in analysis, Salma Kausar, wrote the Abstract,IjazAhmad and Muhammad Atif Ghafoor wrote Materials and Methods and Shahzada Munawar Mehdi, supervised the research work.

\section{Conflict of interest}

The authors have declared no conflict of interest.

\section{References}

Dubey,G.D.,A.S.Parmar,H.S. Kanwer,S.C.Verma and D.K. Mehta. 2013. Effect of micronutrients on plant growth and fruit yield parameters of bell pepper (Capsicum annuum L.) grown under mid hill conditions of Himachal Pradesh. Veg. Sci., 40(1): 107-108.

Fageria, N.K., 2009. The use of nutrients in crop plants. Boca Raton. Fl.: CRC (In Press).

Gogoi, S., M.R. Das, P. Bora and N. Mazumder. 2014. Effect of foliar application of nutrients on fruit and seed production of brinjal (Solanum melongena L.). Indian J. Assam Agric. Sci., 2(12): $23-27$.

Kadari, I.A., E.M. Dheware, B.D. waghmare, S.S. Mingire and K.N. Dhawale. 2015. Influence of micronutrients and biofertilizers on growth, yield and quality attributes of tomato (Lycopersicon esculentum Mill.). Green Farming, 6(1): 74-76.

Khedr, Z.M.A., E.L.E. Fathy and A.M. Moghazy. 2004. Effect of some nutrients and growth substances on productivity of eggplant (Solanum melogena var. esculentum) growing under high temperature conditions. Ann. Agric. Sci., 42(2): 583-602.

Kumar and K. Sodh. 2015. Improvement of growth, yield and quality of tomato (Solanum lycopersicum L.) cv. Azad t-6 with foliar application of zinc and boron. Int. J. Bio-resour. Stress Manage., 6(5): 598-601. https://doi.org/10.5958/0976- 
4038.2015.00091.3

Mohsen, K., 2013. Effects of Zn, Fe and their combination treatments on the growth and yield of tomato. Bull. Environ. Pharmacol. Life Sci., 3(1): 109-114.

Niranjana, R.F., M. Devi, W. Shanika and R.I.P. Sridhar. 2015. Influence of biophysical characteristics of brinjal varieties on the infestation of brinjal shoot and fruit borer, Leucinodes orbonalis Guesnée.J. Univ. Ruhuna, 1: 21-28. https://doi.org/10.4038/jur.v3i1.7861

Pandav, A.K., M.K. Nalla, T. Aslam, M.K. Rana and J.C. Bommesh. 2016. Effect of foliar application of Scientific Research and Innovative micronutrients on growth and yield parameters in eggplant cv. HLB 12 Environ. Ecol., 35(3): 1745-1748.

Sankaran, N., S. Meena and N. Sakthivel. 2005. Input management in maize. Madras Agric. J., 92(7-9): 464-468.

Suganiya, S. and H.D. Kumuthini. 2015. Effect of boron on flower and fruit set and yield of ratoon brinjal crop. Int. J. Sci. Res. Innov. Technol., 2(1): 135-141.

Tawab, Saleha, G. Ayub, Tawab, Faiza, Khan, Owais, N. Bostan, G. Ruby, S. Ahmad and U.K. Afridi. 2015. Response of brinjal (Solanum melongena L.) cultivars to zinc levels. J. Agric. Biol. Sci., 10(5): 172-178. 